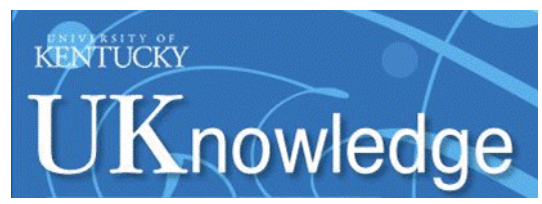

University of Kentucky

UKnowledge

$12-3-2016$

\title{
Individual Differences in Intentional and Unintentional Exposure to Online Pornography Among Hong Kong Chinese Adolescents
}

\author{
Cecilia M. S. Ma \\ The Hong Kong Polytechnic University, China \\ Daniel T. L. Shek \\ University of Kentucky \\ Catie C. W. Lai \\ The Hong Kong Polytechnic University, China
}

Follow this and additional works at: https://uknowledge.uky.edu/pediatrics_facpub

Part of the Child Psychology Commons, Chinese Studies Commons, Developmental Psychology Commons, and the Gender and Sexuality Commons

Right click to open a feedback form in a new tab to let us know how this document benefits you.

\section{Repository Citation}

Ma, Cecilia M. S.; Shek, Daniel T. L.; and Lai, Catie C. W., "Individual Differences in Intentional and Unintentional Exposure to Online Pornography Among Hong Kong Chinese Adolescents" (2016). Pediatrics Faculty Publications. 281.

https://uknowledge.uky.edu/pediatrics_facpub/281

This Article is brought to you for free and open access by the Pediatrics at UKnowledge. It has been accepted for inclusion in Pediatrics Faculty Publications by an authorized administrator of UKnowledge. For more information, please contact UKnowledge@lsv.uky.edu. 


\section{Individual Differences in Intentional and Unintentional Exposure to Online Pornography Among Hong Kong Chinese Adolescents}

\section{Digital Object Identifier (DOI)}

https://doi.org/10.1515/ijdhd-2017-7010

\section{Notes/Citation Information}

Published in International Journal on Disability and Human Development, v. 16, issue 4, p. 417-423.

(C2017 Walter de Gruyter GmbH, Berlin/Boston.

The copyright holder has granted the permission for posting the article here 
Cecilia M.S. Ma*, Daniel T.L. Shek and Catie C.W. Lai

\section{Individual differences in intentional and unintentional exposure to online pornography among Hong Kong Chinese adolescents}

DOI 10.1515/ijdhd-2017-7010

Received August 10, 2016; accepted September 10, 2016; previously published online December 3, 2016

\begin{abstract}
The current study aimed to test how gender and religion affect unintentional and intentional exposure to online pornography in Chinese adolescents. A total of 1401 secondary school students (age range from 11 to 16 years) participated in the study. Findings from multivariate analyses show that males reported higher levels of unintentional and intentional exposure to online pornography than females. Significant differences were found in adolescents' religiosity, with students who had religious beliefs reporting a lower level of unintentional exposure to online pornography than their counterparts without religious beliefs. In terms of intentional exposure to online pornography, adolescents were more likely to be exposed if they were male and had religious beliefs. Such differences were not found in females. This study demonstrated the influence of demographic characteristics on exposure to online pornography among Chinese adolescents.
\end{abstract}

Keywords: Chinese adolescents; gender; online pornography; religion.

\section{Introduction}

The growing use of the Internet makes pornography more affordable and easier to access for adolescents [1-3]. Nowadays, adolescents are frequent users of the Internet for

\footnotetext{
*Corresponding author: Cecilia M.S. Ma, Department of Applied Social Sciences, The Hong Kong Polytechnic University, Hunghom, Hong Kong, P.R. China, E-mail: cecilia.ma@polyu.edu.hk Daniel T.L. Shek: Department of Applied Social Sciences, The Hong Kong Polytechnic University, Hong Kong, P.R. China; Centre for Innovative Programmes for Adolescents and Families, The Hong Kong Polytechnic University, Hong Kong, P.R. China; Department of Social Work, East China Normal University, Shanghai, P.R. China; Kiang Wu Nursing College of Macau, Macau, P.R. China; and Division of Adolescent Medicine, Kentucky Children's Hospital, University of Kentucky, Lexington, KY, USA

Catie C.W. Lai: Department of Applied Social Sciences, The Hong Kong Polytechnic University, Hong Kong, P.R. China
}

information, entertainment and communication [4-6]. Indeed, the Internet provides adolescents with an ideal way to search for sexual information anonymously [3]. This is particularly the case when they enter puberty and show more interest in sex [7]. Much of the previous research has focused on the negative impacts of pornography viewing, such as early sexual involvement [8], uncommitted sexual relationships [9], sexual victimization $[8,10]$, sexual permissiveness [11], objectification of women [12], substance abuse [13, 14], delinquency [10] and low self-worth and depression [15]. Research has been calling for identifying factors of pornography exposure in order to protect our adolescents against this behavior.

Gender is an important antecedent for exposure to online pornography [16]. Males were generally found to be more frequent users of pornography $[13,17,18]$, discuss more often about pornography with their peers [19] and perceive greater peer pressure to use pornography [20] than their female counterparts. Although literature generally supports that gender is an antecedent for exposure to online pornography, little is known about the consumption of different types of pornographic material among males and females. Howard and colleagues found that males were more likely to participate in some online activities, such as joining a chat room and downloading a video or an audio clip [21]. Male Internet users might be at higher risk of engaging in sexual chats or viewing pornographic videos. It is possible that males and females might search for different information or material when using pornography. Therefore, systematic research on exposure to different types of pornographic material by gender is needed.

Besides gender, religion is another possible factor influencing exposure to pornography. Many studies showed that lower consumption of pornography was associated with adolescents who were studying in schools with religious backgrounds [15, 22-24] and attending religious services [15, 24]. Moreover, prior research had demonstrated that religiosity was linked to self-regulation and self-control [22], negative attitudes toward pornography $[22,25]$ and conformity to the social norms and expectations against watching pornography [22]. These findings are also reported in a study examining religious 
communities [26]. It seems that religion might promote more conservative attitudes toward sex [25] and protect adolescents against pornography use [27]. Nevertheless, prior studies addressing links between religion and pornography use are based on samples from Western contexts [22, 23]. It is not clear whether this result can be generalized in non-Western contexts. The aim of the present study was to explore how pornography use varies by religious background among Chinese adolescents.

Lastly, the nature of exposure has recently been studied in this area of research. Researchers suggested that as frequent users of the Internet, adolescents tend to be exposed to online pornography by chance $[5,18]$, such as some pop-up pornographic advertisements when browsing the Internet. Mitchell and colleagues [28] also noted that the wide availability of online pornography may lead to unintentional exposure to such material. Recently, Peter and Valkenburg [29] conducted a systematic review of the literature on adolescents' consumption of pornography and highlighted the importance of distinguishing between intentional and unintentional exposure of online pornography. It seems that factors linking exposure to pornography may vary with viewers' intentions when searching the Internet. Therefore, studies for identifying factors related to exposure to online pornography should examine intentional and unintentional exposure separately.

In sum, the prevalence of the Internet has led to an increase of exposure to online pornography. Adolescents are a high-risk population to be exposed to online pornography due to increased curiosity about sex and high frequency of Internet use. Some demographic factors, such as gender and religiosity, have significant impacts on the frequency of exposure to online pornography. Recent literature suggests that exposure to online pornography should be categorized as intentional and unintentional. Therefore, research on exposure to different types of pornographic material by gender and with or without religious background is needed. There were two purposes of the present study. First, we explored the prevalence of intentional and unintentional online pornography among a sample of Chinese adolescents. Second, we examined whether the two types of exposure differed by gender and religious background.

\section{Methods}

A total of 1401 Chinese secondary school students including 753 males (54\%) and 639 females (46\%) were recruited from 13 secondary schools [age range from 11 to 16 years, mean $(M)=12.43$, standard deviation $(\mathrm{SD})=0.70]$. Nine respondents failed to indicate their gender. Before data collection, students and their parents were contacted and informed about the purpose, procedures and confidentiality safeguards of the study. Ethical approval was obtained from the Hong Kong Polytechnic University Review Board. In general, it took around $15 \mathrm{~min}$ to complete the survey.

\section{Exposure to online pornography}

Six items were used to determine the frequency of unintentional exposure to six different types of online pornographic material, including (a) stories, (b) pictures, (c) videos, (d) pornographic advertisements, (e) websites and (f) chat rooms over the past half year. The same questions were asked about the frequency of intentional exposure to online pornographic material. The responses were $0=$ never, $1=$ less than once a month, $2=$ once to three times a month, $3=$ once $a$ week, $4=$ several times a week and $5=$ everyday. The internal consistency of both scales was satisfactory (unintentional: $\alpha=0.78$; intentional: $\alpha=0.83$ ).

\section{Demographic information}

Students answered three items to indicate their gender $(0=$ male; $1=$ female), age and religiosity $(0=$ yes; $1=$ no).

\section{Data analysis}

Independent t-tests were conducted to determine gender differences in a mean score of 12 items of unintentional and intentional exposure to online pornography. The same analysis was performed to find whether religiosity caused any differences in the items. To examine whether gender and religiosity jointly affected the two types of exposure to online pornography, a series of multivariate analyses of covariance (MANCOVA) were carried out by including an interaction term with two dichotomous variables (gender and religiosity) and age as a covariate. All analyses were performed by SPSS for Windows (version 22.0).

\section{Results}

The prevalence rates of the two types of exposure to online pornography are shown in Tables 1 and 2. About 4\% (ranging from $2 \%$ to $6 \%$ ) had unintentionally exposed themselves to online pornography (see Table 1), while 9\% (ranging from $4 \%$ to $14 \%$ ) of the respondents had intentionally exposed themselves to online pornography (see Table 2). In terms of intentional exposure, $14 \%(n=197)$ had viewed pornographic pictures and around 13\% had watched pornographic advertisements $(n=179)$ in the past 6 months.

In Table 3, males reported higher levels of both types of exposure to online pornography (unintentional: 5\%-16\%; intentional: $2 \%-8 \%$ ) than females (unintentional: 4\%-11\%; intentional: $1 \%-5 \%$ ). In Table 4, 
Table 1: Frequencies of intentional exposure to online pornography.

\begin{tabular}{|c|c|c|c|c|c|c|}
\hline $\begin{array}{l}\text { Over the past } 6 \text { months, have you ever } \\
\text { intentionally searched the Internet to }\end{array}$ & Never & $\begin{array}{r}\text { Less than } \\
\text { once a month }\end{array}$ & $\begin{array}{r}1-3 \text { times } \\
\text { a month }\end{array}$ & $\begin{array}{r}\text { About once } \\
\text { a week }\end{array}$ & $\begin{array}{r}\text { Several } \\
\text { times a week }\end{array}$ & Daily \\
\hline $\begin{array}{l}\text { 1. Read erotic stories (including comic } \\
\text { stories)? }\end{array}$ & $90.1 \%$ & $6.7 \%$ & $1.8 \%$ & $0.7 \%$ & $0.4 \%$ & $0.4 \%$ \\
\hline $\begin{array}{l}\text { 2. View pornographic pictures (showing } \\
\text { genital areas/naked bodies)? }\end{array}$ & $85.9 \%$ & $10.1 \%$ & $2.1 \%$ & $1 \%$ & $0.6 \%$ & $0.2 \%$ \\
\hline $\begin{array}{l}\text { 3. View pornographic videos (including } \\
\text { cartoon videos)? }\end{array}$ & $89.6 \%$ & $7.2 \%$ & $1.9 \%$ & $0.6 \%$ & $0.4 \%$ & $0.2 \%$ \\
\hline 4. Engage in sexual chats? & $95.8 \%$ & $3 \%$ & $0.5 \%$ & $0.4 \%$ & $0.2 \%$ & $0.1 \%$ \\
\hline 5. View pornographic advertisements? & $87.2 \%$ & $9.4 \%$ & $2.1 \%$ & $0.7 \%$ & $0.4 \%$ & $0.2 \%$ \\
\hline 6. Browse pornographic websites? & $93.8 \%$ & $4.4 \%$ & $1 \%$ & $0.4 \%$ & $0.4 \%$ & $0.1 \%$ \\
\hline
\end{tabular}

Table 2: Frequencies of unintentional exposure to online pornography.

\begin{tabular}{|c|c|c|c|c|c|c|}
\hline $\begin{array}{l}\text { Over the past } 6 \text { months, while online, have } \\
\text { you ever unintentionally been exposed to }\end{array}$ & Never & $\begin{array}{l}\text { Less than } \\
\text { once a month }\end{array}$ & $\begin{array}{r}1-3 \text { times } \\
\text { a month }\end{array}$ & $\begin{array}{r}\text { About once } \\
\text { a week }\end{array}$ & $\begin{array}{r}\text { Several } \\
\text { times a week }\end{array}$ & Daily \\
\hline 1. Erotic stories (including comic stories)? & $94.9 \%$ & $2.9 \%$ & $1.1 \%$ & $0.3 \%$ & $0.5 \%$ & $0.3 \%$ \\
\hline $\begin{array}{l}\text { 2. Pornographic pictures (showing genital } \\
\text { areas/naked bodies)? }\end{array}$ & $94.7 \%$ & $3.3 \%$ & $1.1 \%$ & $0.4 \%$ & $0.4 \%$ & $0.1 \%$ \\
\hline $\begin{array}{l}\text { 3. Pornographic videos (including cartoon } \\
\text { videos)? }\end{array}$ & $93.6 \%$ & $3.6 \%$ & $1.7 \%$ & $0.5 \%$ & $0.5 \%$ & $0.1 \%$ \\
\hline 4. Sexual chat rooms? & $97.9 \%$ & $1.4 \%$ & $0.1 \%$ & $0.1 \%$ & $0.3 \%$ & $0.1 \%$ \\
\hline 5. Pornographic advertisements? & $98.4 \%$ & $1.4 \%$ & $0.1 \%$ & $0.1 \%$ & $0.1 \%$ & $0.1 \%$ \\
\hline 6. Pornographic websites? & $96.1 \%$ & $2.3 \%$ & $0.9 \%$ & $0.3 \%$ & $0.4 \%$ & $0.1 \%$ \\
\hline
\end{tabular}

Table 3: Frequencies of unintentional and intentional exposure to online pornography by gender.

\begin{tabular}{|c|c|c|c|c|}
\hline & \multicolumn{2}{|c|}{ Unintentionally } & \multicolumn{2}{|c|}{ Intentionally } \\
\hline & Male & Female & Male & Female \\
\hline 1. Reading erotic stories (including comic stories) & $11.2 \%$ & $8.3 \%$ & $5.3 \%$ & $4.7 \%$ \\
\hline 2. Viewing pornographic pictures (showing genital areas/naked bodies) & $16.4 \%$ & $11.4 \%$ & $6.4 \%$ & $4.1 \%$ \\
\hline 3. Viewing pornographic videos (including cartoon videos) & $12.0 \%$ & $8.5 \%$ & $8.3 \%$ & $4.4 \%$ \\
\hline 4. Engaging in sexual chats & $4.7 \%$ & $3.8 \%$ & $2.4 \%$ & $2.7 \%$ \\
\hline 5. Viewing pornographic advertisements & $14.5 \%$ & $11.0 \%$ & $1.9 \%$ & $1.4 \%$ \\
\hline 6. Browsing pornographic websites & $7.6 \%$ & $4.5 \%$ & $5.2 \%$ & $2.5 \%$ \\
\hline
\end{tabular}

Table 4: Frequencies of intentional exposure to online pornography by religiosity.

\begin{tabular}{|c|c|c|c|c|}
\hline & \multicolumn{2}{|c|}{ Unintentional } & \multicolumn{2}{|c|}{ Intentional } \\
\hline & Yes & No & Yes & No \\
\hline 1. Reading erotic stories (including comic stories) & $6.8 \%$ & $10.7 \%$ & $4.2 \%$ & $5.0 \%$ \\
\hline 2. Viewing pornographic pictures (showing genital areas/naked bodies) & $11.0 \%$ & $15.5 \%$ & $4.0 \%$ & $6.2 \%$ \\
\hline 3. Viewing pornographic videos (including cartoon videos) & $8.9 \%$ & $11.2 \%$ & $5.4 \%$ & $6.7 \%$ \\
\hline 4. Engaging in sexual chats & $3.5 \%$ & $5.0 \%$ & $0.7 \%$ & $2.7 \%$ \\
\hline 5. Viewing pornographic advertisements & $10.1 \%$ & $14.2 \%$ & $0.9 \%$ & $2.3 \%$ \\
\hline 6. Browsing pornographic websites & $4.2 \%$ & $7.6 \%$ & $3.5 \%$ & $4.6 \%$ \\
\hline
\end{tabular}


students with religious beliefs reported lower levels of both types of exposure to online pornography (unintentional: $4 \%-11 \%$; intentional: $1 \%-5 \%$ ) than their counterparts with no religious beliefs (unintentional: $5 \%-16 \%$; intentional: $2 \%-7 \%$ ).

For unintentional exposure to online pornography, males reported significantly higher levels in all materials than females $(\mathrm{p}<0.05)$, except visiting the chat room $[t(1387)=1.13, \mathrm{p}>0.05$, Table 5]. Similarly, more males intentionally exposed themselves to pornographic pictures $[t(1388)=2.33, \mathrm{p}<0.05$, Table 5], videos $[t(1387)=3.03, \mathrm{p}<0.01$, Table 5$]$ and websites $[t$ $(1387)=3.13, \mathrm{p}<0.01]$.
Adolescents' religiosity was significantly associated with their unintentional exposure to erotic stories [ $t(1126)=-2.27, \mathrm{p}<0.05$, Table 6] and pornographic pictures $[t(1126)=-2.42, \mathrm{p}<0.05$, Table 6]. No significant difference was found in intentional exposure to online pornography, regardless of the sources $(\mathrm{p}>0.05)$.

The interaction effect of gender and religion was not significant in unintentional exposure to online pornography $\left(F_{(1,111)}=0.05, \mathrm{p}>0.05\right)$. Significant differences were found in gender $\left(F_{(1,1112)}=5.55, \mathrm{p}<0.05, \eta^{2}=0.005\right.$, Table 7) and religiosity $\left(F_{(1,1112)}=6.49, \mathrm{p}<0.05, \eta^{2}=0.006\right.$, Table 8). As expected, the majority of the males reported a higher level of unintentional exposure to online

Table 5: Independent t-test results among the two types of exposure to pornographic material by gender.

\begin{tabular}{|c|c|c|c|c|c|c|}
\hline & \multicolumn{3}{|c|}{ Unintentional } & \multicolumn{3}{|c|}{ Intentional } \\
\hline & $\begin{array}{r}\text { Male } \\
\text { M (SD) }\end{array}$ & $\begin{array}{l}\text { Female } \\
M \text { (SD) }\end{array}$ & $\boldsymbol{t}$ & $\begin{array}{r}\text { Male } \\
\text { M (SD) }\end{array}$ & $\begin{array}{r}\text { Female } \\
M(S D)\end{array}$ & \\
\hline 1. Erotic stories (including comic stories) & $0.18(0.64)$ & $0.12(0.45)$ & $2.19^{\mathrm{a}}$ & $0.11(0.54)$ & $0.08(0.40)$ & 1.10 \\
\hline 2. Pornographic pictures (showing genital areas/naked bodies) & $0.25(0.69)$ & $0.16(0.51)$ & $2.64^{\mathrm{b}}$ & $0.11(0.51)$ & $0.06(0.32)$ & $2.33^{\mathrm{a}}$ \\
\hline 3. Pornographic videos (including cartoon videos) & $0.18(0.60)$ & $0.12(0.48)$ & $1.99^{\mathrm{a}}$ & $0.15(0.59)$ & $0.07(0.37)$ & $3.02^{\mathrm{b}}$ \\
\hline 4. Sexual chat rooms & $0.08(0.41)$ & $0.05(0.31)$ & 1.13 & $0.05(0.41)$ & $0.02(0.21)$ & 1.59 \\
\hline 5. Pornographic advertisements & $0.22(0.65)$ & $0.14(0.45)$ & $2.52^{\mathrm{a}}$ & $0.03(0.25)$ & $0.01(0.12)$ & 1.27 \\
\hline 6. Pornographic websites & $0.12(0.50)$ & $0.06(0.32)$ & $2.38^{\mathrm{a}}$ & $0.10(0.51)$ & $0.03(0.23)$ & $3.13^{b}$ \\
\hline
\end{tabular}

${ }^{\mathrm{a}} \mathrm{p}<0.05 ;{ }^{\mathrm{b}} \mathrm{p}<0.01$.

Table 6: Independent t-test results among the two types of exposure to pornographic material by religiosity.

\begin{tabular}{|c|c|c|c|c|c|c|}
\hline & \multicolumn{3}{|c|}{ Unintentional } & \multicolumn{3}{|c|}{ Intentional } \\
\hline & $\begin{array}{r}\text { Yes } \\
M(S D)\end{array}$ & $\begin{array}{r}\text { No } \\
M(S D)\end{array}$ & $t$ & $\begin{array}{r}\text { Yes } \\
M(S D)\end{array}$ & $\begin{array}{r}\text { No } \\
M(S D)\end{array}$ & \\
\hline 1. Erotic stories (including comic stories) & $0.10(0.42)$ & $0.17(0.59)$ & $-2.27^{\mathrm{a}}$ & $0.08(0.42)$ & $0.09(0.50)$ & -0.61 \\
\hline 2. Pornographic pictures (showing genital areas/naked bodies) & $0.15(0.51)$ & $0.24(0.70)$ & $-2.42^{\mathrm{a}}$ & $0.09(0.48)$ & $0.10(0.45)$ & -0.44 \\
\hline 3. Pornographic videos (including cartoon videos) & $0.14(0.52)$ & $0.18(0.60)$ & -1.13 & $0.10(0.50)$ & $0.12(0.52)$ & -0.51 \\
\hline 4. Sexual chat rooms & $0.05(0.30)$ & $0.08(0.39)$ & -1.22 & $0.02(0.28)$ & $0.04(0.32)$ & -1.17 \\
\hline 5. Pornographic advertisements & $0.15(0.55)$ & $0.21(0.60)$ & -1.58 & $0.01(0.17)$ & $0.03(0.25)$ & -1.19 \\
\hline 6. Pornographic websites & $0.07(0.40)$ & $0.12(0.48)$ & -1.62 & $0.08(0.48)$ & $0.07(0.40)$ & 0.33 \\
\hline
\end{tabular}

${ }^{\mathrm{a} p}<0.05$.

Table 7: Differences in unintentional exposure to online pornography by gender.

\begin{tabular}{|c|c|c|c|}
\hline \multicolumn{2}{|l|}{ Gender } & \multirow[t]{2}{*}{$F$} & \multirow[t]{2}{*}{$\eta^{2}$} \\
\hline $\begin{array}{l}\text { Male } \\
\text { M (SD) }\end{array}$ & $\begin{array}{l}\text { Female } \\
\text { M (SD) }\end{array}$ & & \\
\hline $0.17(0.43)$ & $0.11(0.30)$ & $5.55^{\mathrm{a}}$ & 0.005 \\
\hline
\end{tabular}

Table 8: Differences in unintentional exposure to online pornography by religiosity.

\begin{tabular}{lrrrr}
\hline Religious & & & $F$ & $\eta^{2}$ \\
\hline $\begin{array}{l}\text { Yes } \\
M(S D)\end{array}$ & No & & \\
\hline $0.11(0.29)$ & $0.16(0.42)$ & & $6.49^{\mathrm{a}}$ & 0.000 \\
\hline $\mathrm{a}<0.05$. & & &
\end{tabular}


Table 9: MANCOVA results of the two types of exposure to online pornography by religiosity and gender.

\begin{tabular}{|c|c|c|c|c|c|c|}
\hline & \multicolumn{2}{|r|}{ Yes } & \multicolumn{2}{|r|}{ No } & \multirow[t]{2}{*}{$F$} & \multirow[t]{2}{*}{$\eta^{2}$} \\
\hline & $\begin{array}{r}\text { Male } \\
M(S D)\end{array}$ & $\begin{array}{l}\text { Female } \\
M(S D)\end{array}$ & $\begin{array}{r}\text { Male } \\
\text { M (SD) }\end{array}$ & $\begin{array}{l}\text { Female } \\
\text { M (SD) }\end{array}$ & & \\
\hline 1. Unintentional & $0.13(0.34)$ & $0.19(0.47)$ & $0.08(0.22)$ & $0.13(0.35)$ & 0.05 & 0.000 \\
\hline 2. Intentional & $0.11(0.40)$ & $0.08(0.36)$ & $0.01(0.08)$ & $0.07(0.26)$ & $4.32^{a}$ & 0.004 \\
\hline
\end{tabular}

${ }^{\mathrm{a} p}<0.05$

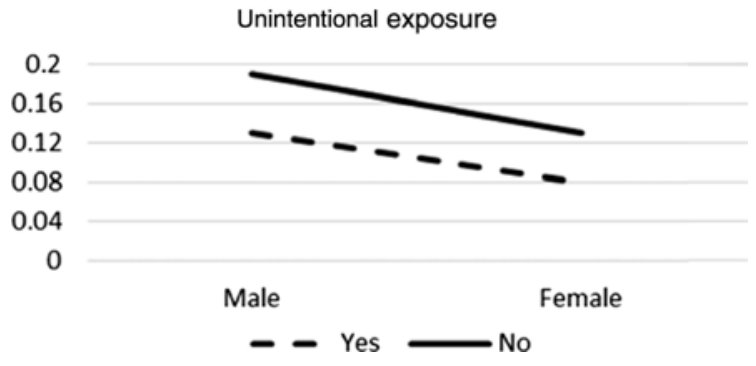

Figure 1: Unintentional exposure to online pornography by gender and religiosity.

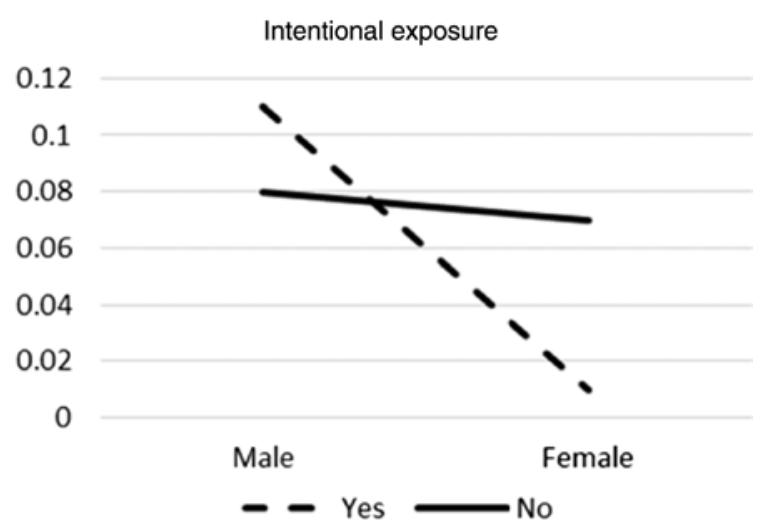

Figure 2: Intentional exposure to online pornography by gender and religiosity.

Table 10: Linear regression models predicting unintentional and intentional exposure to online pornography by religiosity.

\begin{tabular}{|c|c|c|c|c|c|c|}
\hline \multirow[t]{2}{*}{ Predictor } & \multicolumn{3}{|c|}{ Unintentional } & \multicolumn{3}{|c|}{ Intentional } \\
\hline & $\mathbf{R}$ & $\mathbf{R}^{2}$ & $\beta^{a}$ & $\mathbf{R}$ & $\mathbf{R}^{2}$ & $\boldsymbol{\beta}^{\mathrm{a}}$ \\
\hline Gender & & & $-0.08^{c}$ & & & $-0.07^{b}$ \\
\hline Religiosity & & & $-0.07^{b}$ & & & -0.02 \\
\hline Model & 0.11 & 0.01 & & 0.07 & 0.01 & \\
\hline
\end{tabular}

aStandardized coefficients. ${ }^{b} p<0.05,{ }^{c} p<0.01$.

pornography $[\mathrm{M}=0.16$, standard error $(\mathrm{SE})=0.02]$ than females $(M=0.11, S E=0.02)$. Also, students with religious backgrounds had a lower level of such exposure
$(\mathrm{M}=0.10, \mathrm{SE}=0.02)$ than those without religious backgrounds $(M=0.16, S E=0.02)$.

Based on the MANCOVA results, a significant interaction effect of gender and religious beliefs was found in intentional exposure $\left(F_{(1,111)}=4.32, \mathrm{p}<0.05, \eta^{2}=0.004\right.$, Table 9). For intentional exposure, females with religious beliefs reported a lower level of mean score $(M=0.01$, $\mathrm{SE}=0.02)$ than their non-religious counterparts $(\mathrm{M}=0.07$, $\mathrm{SE}=0.02)$. Conversely, males with religious beliefs showed a higher level of intentional exposure to online pornography $(M=0.11, S E=0.02)$ than their counterparts with no religious beliefs $(M=0.08, S E=0.02)$. These results are shown in Figures 1 and 2. Linear regression models were performed to test the predictive effects of gender and religion on both types of exposure to online pornography. In Table 10, the results showed that gender was significantly associated with both unintentional $(\beta=-0.08$, $\mathrm{p}<0.01)$ and intentional exposure $(\beta=-0.07, \mathrm{p}<0.05)$ to online pornography. Regardless of the nature of exposure, females were less likely to be exposed to this material than males. Religion had a significant predictive effect on unintentional exposure $(\beta=-0.07, p<0.05)$ but not on intentional exposure $(\beta=-0.02, p>0.05)$ to online pornography. Adolescents, particularly those with religious beliefs, were more likely to be unintentionally exposed to pornographic material than those without religious beliefs.

\section{Discussion}

The current study extends the scientific literature on consumption of pornographic material in three ways. First, contrary to prior studies [10], adolescents reported more unintentional exposure to pornography than intentional exposure. However, it is important to note that the prevalence rates for intentional and unintentional exposure are generally low (unintentional: 4\%-14\%; intentional: $2 \%-6 \%$ ), compared to studies conducted in Australia [84\% males, 60\% females (aged 16-17 years) were unintentionally exposed] [8], Taiwan (41\% unintentional, 
59\% intentional among Grade 10-12 students) [30] and the United States (63\% intentional and 32\% unintentional among 15-18-year-old adolescents) [22].

One possible reason might be related to the age of our sample. Sex is considered as taboo in Chinese society. Viewing pornography, even unintentionally, is undesirable and contradicts traditional Chinese values [31]. Given that the majority of the participants of the present study were early adolescents, they might be embarrassed to admit that they were intentionally exposed to pornographic material. More research in exploring the prevalence of both types of online pornography use is suggested.

Second, adolescents with religious beliefs reported a lower level of unintentional exposure to online pornography than their counterparts without religious beliefs. Uecker [26] suggested that religion might serve as another way of social control against negative behavior. Prior studies showed that religious youth have a higher level of self-regulation [32], greater self-control [33], lower level of risky sexual behavior $[34,35]$ and are less likely to use pornography (intentionally or unintentionally) [15, 22, 23]. Religious beliefs also help adolescents to form "correct" sexual values such as respecting the body of the opposite sex and "inappropriateness" of seeing the bodies of the opposite sex outside marriage. The present findings extend the literature by demonstrating the protective effects of religion against negative behavior in a non-Western culture.

Third, interestingly, the link between intentional exposure to online pornography and religiosity varied with gender. Aligned with previous literature, the protective effect of religiosity was found in females. In contrast, compared to males without a religious background, males with religious beliefs showed a greater level of being intentionally exposed to online pornography. Religiosity has long been posited as a factor contributing to a more conservative attitude toward sexuality [25]. Although males with religious beliefs are being stimulated by their sexual interest and curiosity, they face social pressure to abstain from their sexual needs. Instead of exploring their sexual identity in real life, they actively search for online pornography, which provides them with "a protective cloak of anonymity" [36] and emotional support from others [37]. The present study highlights the interaction of demographic characteristics when studying the antecedents of this behavior. Future research should explore the effects of different combinations of demographic factors on the use of online pornography.

Several limitations should be noted for this study. First, as our findings were based on a cross-sectional design, causal relationships between the antecedents and exposure to online pornography cannot be concluded. A future study using a longitudinal design would help uncover the correlates and their influences on both types of exposure to online pornography. Second, the nature of Internet activity might affect the frequency of intentional and unintentional exposure to online pornography. Ševčíková and colleagues [38] found that gender was significantly related to unintentional exposure to online pornography when adolescents visited X-rated and peerto-peer sharing websites, but not social networking sites. The nature of online activities should perhaps be included when studying how gender is related to exposure to online pornography. The present study did not examine their involvement and internalization of religiousness. A prior study found that these factors exerted protective effects on adolescents' consumption of pornography [22]. More work is warranted to investigate the influence of different aspects of religiousness on pornography viewing.

In conclusion, the current study showed lower levels of unintentional and intentional exposure to online pornography at a younger age among Chinese adolescents. Regarding the frequency of exposure, male adolescents with a religious background were likely to be more frequently exposed to online pornography. Perhaps, the secrecy and solitary nature of the Internet provided an ideal place to satisfy this target population's needs and curiosity due to their higher interest in sexuality. Further, this study provides support for arguments on the necessity to differentiate the nature of exposure to online pornography [22, 23]. Lastly, the present findings identified the protective role of religion and suggested the possibility of using religion when designing sexual prevention programs for Chinese adolescents.

Acknowledgments: The present study is funded by a grant (Grant no. 25401414) of the Early Career Scheme of the Research Grants Council of the University Grants Committee of Hong Kong.

\section{References}

1. Beaver W. The dilemma of internet pornography. Bus Soc Rev 2000;105:373-82.

2. Buzzell T. The effects of sophistication, access and monitoring on use of pornography in three technological contexts. Deviant Behav 2005;26:109-32.

3. Cooper A. Sexuality and the internet: surfing into the new millennium. Cyberpsychol Behav 1998;1:187-93.

4. Lenhart A, Maddenn M, Hitlin P. Teens and technology: youth are leading the transition to a fully wired and mobile nation. Washington, DC: Pew Internet American Life Project, 2005. 
5. Livingstone S, Helsper EJ. Taking risks when communicating on the internet: the role of offline social-psychological factors in young people's vulnerability to online risks. Inform Commun Soc 2007;10:619-44.

6. Mesch G, Talmud I. The quality of online and offline relationships: the role of multiplexity and duration of social relationships. Inform Soc 2006;22:137-48.

7. Flannery DJ, Rowe DC, Gulley BL. Impact of pubertal status, timing, and age on adolescent sexual experience and delinquency. J Adolesc Res 1993;8:21-40.

8. Flood M. Exposure to pornography among youth in australia. J Sociol 2007;43:45-60.

9. Byrne D, Osland JA. Sexual fantasy and erotica/pornography: internal and external imagery. Psychol Pers Hum Sex 2000:283-305.

10. Wolak J, Mitchell K, Finkelhor D. Unwanted and wanted exposure to online pornography in a national sample of youth Internet users. Pediatrics 2007;119:247-57.

11. Braun-Courville DK, Rojas M. Exposure to sexually explicit web sites and adolescent sexual attitudes and behaviors. J Adolesc Health 2009;45:156-62.

12. Peter J, Valkenburg PM. Adolescents' exposure to a sexualized media environment and their notions of women as sex objects. Sex Roles 2007;56:381-95.

13. Carroll JS, Padilla-Walker LM, Nelson LJ, Olson CD, Barry CM, Madsen SD. Generation XXX pornography acceptance and use among emerging adults. J Adolesc Res 2008;23:6-30.

14. Svedin CG, Åkerman I, Priebe G. Frequent users of pornography: a population based epidemiological study of swedish male adolescents. J Adolesc 2011;34:779-88.

15. Nelson LJ, Padilla-Walker LM, Carroll JS. “I believe it is wrong but I still do it”: a comparison of religious young men who do versus do not use pornography. Psychol Relig Spiritual 2010;2:136-47.

16. Vandenbosch L. Antecedents of adolescents' exposure to different types of sexually explicit Internet material: a longitudinal study. Comput Human Behav 2015;50:439-48.

17. Traeen B, Spitznogle K, Beverfjord A. Attitudes and use of pornography in the norwegian population 2002. J Sex Res 2004;41:193.

18. Ybarra ML, Mitchell KJ. Exposure to internet pornography among children and adolescents: a national survey. Cyberpsychol Behav 2005;8:473-86.

19. Vanden Abeele M, Campbell SW, Eggermont S, Roe K. Sexting, mobile porn use, and peer group dynamics: boys' and girls' selfperceived popularity, need for popularity, and perceived peer pressure. Media Psychol 2014;17:6-33.

20. Weber M, Quiring O, Daschmann G. Peers, parents and pornography: exploring adolescents' exposure to sexually explicit material and its developmental correlates. Sex Cult 2012;16:408-27.
21. Howard PE, Rainie L, Jones S. Days and nights on the internet. In: Wellman B, Haythornwaite C, editors. The internet in everyday life. Oxford, UK: Blackwell, 2002:45-74.

22. Hardy SA, Steelman MA, Coyne SM, Ridge RD. Adolescent religiousness as a protective factor against pornography use. J Appl Dev Psychol 2013;34:131-9.

23. Mesch GS. Social bonds and internet pornographic exposure among adolescents. J Adolesc 2009;32:601-18.

24. Stack S, Wasserman I, Kern R. Adult social bonds and use of Internet pornography. Soc Sci Q 2004;85:75-88.

25. Regnerus MD. Forbidden fruit: Sex and religion in the lives of American teenagers. Oxford: Oxford University Press, 2009.

26. Uecker JE. Religion, pledging, and the premarital sexual behavior of married young adults. J Marriage Fam 2008;70:728-44.

27. Sherkat DE, Ellison CG. The cognitive structure of a moral crusade: conservative protestantism and opposition to pornography. Soc Forces 1997;75:957-80.

28. Mitchell KJ, Finkelhor D, Wolak J. The exposure of youth to unwanted sexual material on the internet a national survey of risk, impact, and prevention. Youth Soc 2003;34:330-58.

29. Peter J, Valkenburg PM. Adolescents and pornography: a review of 20 years of research. J Sex Res 2016;53:509-31.

30. Chen AS, Leung M, Chen CH, Yang SC. Exposure to internet pornography among taiwanese adolescents. Soc Behav Pers 2013;41:157-64.

31. Thornburgh D, Lin HS. Youth, pornography, and the internet. Washington, DC: National Academies Press, 2002.

32. Crockett LJ, Raffaelli M, Shen YL. Linking self-regulation and risk proneness to risky sexual behavior: pathways through peer pressure and early substance use. J Adolesc Res 2006;16:503-25.

33. McCullough ME, Willoughby BL. Religion, self-regulation, and self-control: associations, explanations, and implications. Psychol Bull 2009;135:69-93.

34. Dowshen N, Forke CM, Johnson AK, Kuhns LM, Rubin D, Garofalo R. Religiosity as a protective factor against HIV risk among young transgender women. J Adolesc Health 2011;48:410-4.

35. Ogland CP, Xu X, Bartkowski JP, Ogland EG. The association of religion and virginity status among Brazilian adolescents. J Adolesc Health 2011;48:651-3.

36. McKenna KY, Bargh JA. Plan 9 from cyberspace: The implications of the Internet for personality and social psychology. Pers Soc Psychol Rev 2000;4:57-75.

37. Derlega VJ, Metts S, Petronio S, Margulis ST. Self-disclosure. Newbury Park, CA: Sage, 1993.

38. Ševčíková A, Daneback K. Online pornography use in adolescence: age and gender differences. Eur J Dev Psychol 2014;11:674-86. 